Journal of Animal and Veterinary Advances 9 (16): 2200-2206, 2010

ISSN: $1680-5593$

(C) Medwell Journals, 2010

\title{
Locality and its Importance in Pure Hair Goat Raising (Capra hircus L.): Example from the Teke Region
}

\author{
${ }^{1}$ Sultan Bekiroglu and ${ }^{2}$ Ahmet Tolunay \\ ${ }^{1}$ Faculty of Forestry, University of Istanbul, 34473 Bahcekoy, Istanbul, Turkey \\ ${ }^{2}$ Faculty of Forestry, University of Suleyman Demirel, 32260, Cunur, Isparta, Turkey
}

\begin{abstract}
The goal of this study is to designate the local differences in terms of pure hair goat population, forests, ranges, population and income factors as well as the relations between these factors in the Teke Region which is one of the regions with the highest density of pure hair goat population in Turkey. The study material is comprised of 264 settlement units raising goats in the Teke Region. The sample sizes have been determined with layered and simple random sampling techniques. Nonparametric methods have been used in the statistical analyses and the tests have been performed by using the program Statistical Package for Social Sciences 11.0. The results have been verified at a signified level of $5 \%$. At the end of the study, it was revealed that the provinces of Afyon, Burdur and Isparta which are among the main settlement units in the Teke Region are different from each other in terms of factors such as pure hair goats, forests and ranges. It was determined that there is a significant yet weak relation between pure hair goat population and forests, ranges, population and the income gained from other resources and that there is a strong relation between the income gained from goats and the total income.
\end{abstract}

Key words: Pure hair goat, Silvopastoral systems, locality, Teke Region, random, Turkey

\section{INTRODUCTION}

In regions where the ecological and socioeconomic conditions are harsh and the amount of the land suitable for agriculture is not sufficient, economic activities are usually related with goats. Although there is a high number of goat races that may be raised (Toggenburg, Alpin, Saanen and Boer, etc.), pure hair goats (Capra hircus L.) are preferred in the Teke Region as in Turkey in general due to their adaptation to hard living conditions. Regions where pure hair goat production is mostly widespread are the Aegean, Mediterranean and Southeast Anatolian Regions.

Nomads living in these areas have been raising pure hair goats since centuries in the upper basin of these regions. Pure hair goat raising is the symbol of a cultural value in addition to being a production system for nomads (Fig. 1).

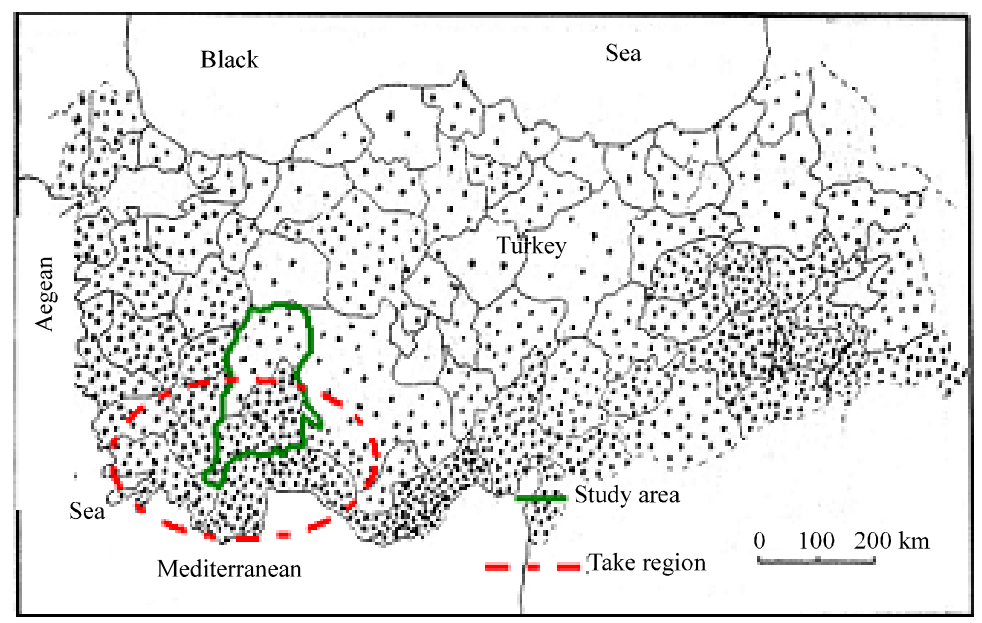

Fig. 1: Distribution of pure hair population in Turkey

Corresponding Author: Sultan Bekiroglu, Faculty of Forestry, University of Istanbul, 34473 Bahcekoy, Istanbul, Turkey 
When a problem is faced regarding pure hair goat raising, an a priori homogeneity understanding is generally displayed and the same solution is applied for each area or region. This a priori homogeneity approach is displayed in many applications of the Ministry of Environment of Forestry of Turkey (MEFT). An example of this approach is the action plan initiated by the relevant ministry in 2008 for Reduction of the Harms of Goats (MEFT, 2008).

Yet, it is crucial for a plan which may give rise to major consequences on a national and international level to recognize the differences in the units within the coverage area in terms of the planning factors taken into account.

In this study, the differences in the factors such as pure hair goat population, forests, ranges, population and income in the Teke Region which is one of regions raising the highest number of pure hair goats in Turkey and the relations between these factors have been determined.

\section{MATERIALS AND METHODS}

Study area: The study area is composed of the Provinces of Afyon, Burdur and Isparta in the Teke Region located in the southwestern part of Turkey (Fig. 2). The Teke Region is an area where pure hair goat raising is widely performed in Turkey. One of the main economic activities of this area is to raise pure hair goats (Temurcin, 2004; Bassullu and Tolunay, 2010a, b). In fact, the word Teke means goat in Turkish.

There are 315,000 pure hair goats in the three Provinces located in the study area. However, pure hair goats are mostly raised in the Provinces of Burdur and Isparta (SPO, 1996a, b; Babalik and Fakir, 2007).
The demographic properties and forest resource information of these provinces have been shown in Table 1. Coniferous forests areas and broad-leaved forest areas; population of forest villagers population and population of pure hair goats raised and average income per family in the forest villages and per capita number of goats in the study area have been shown in Fig. 3-5, respectively (MEFT, 2006, 2008).

Although, the total area is smaller than the two other provinces, the broad-leaved forest area and the total forest area of the Province of Burdur is larger. It is possible to observe in Fig. 3 and 4 that there is a reverse relation between the number of pure hair goats per forest villager.

Material: The study material is composed of 12 factor (variable) data relating to pure hair goats, forests, ranges, population and income of 264 settlement units raising pure hair goats in the Teke Region. Out of the 264 settlement units, 32 belong to the Province of Afyon, 94 belong to the Province of Burdur and 138 belong to the province of Isparta.

Twelve variables related with pure hair goats, forests, population, pasturesand income have been used in this research (Table 2).

Methods: In this study, the conformity of variable data distribution to the normal distribution, the direction and power of the relations between the variables and whether the Provinces of Afyon-Burdur-Isparta constitute the units belonging to the same main society (their similarities and differences) have been determined with nonparametric methods. The following hypotheses have been formulated for the statistical analyses for the purpose of fulfilling the objective of the research:

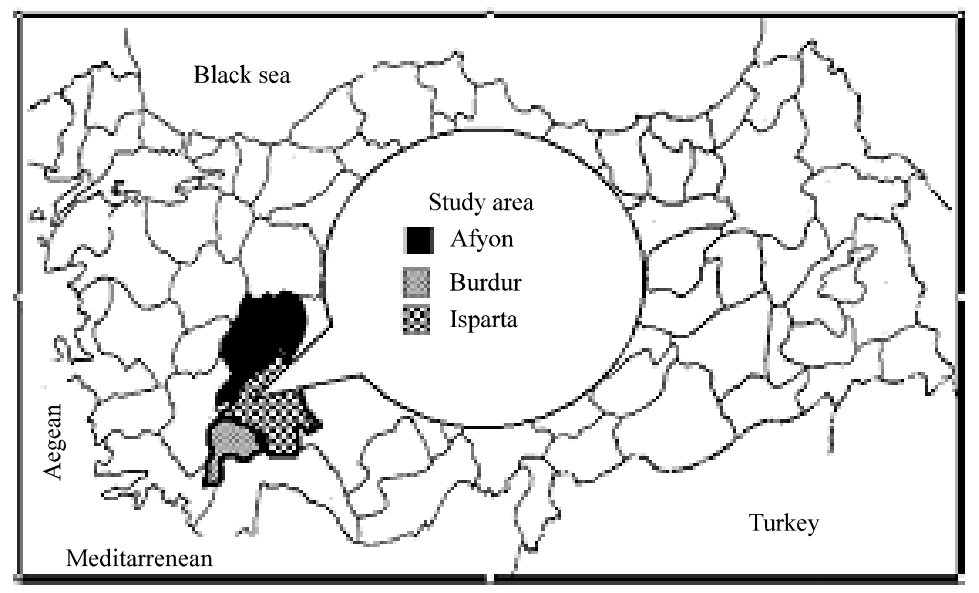

Fig. 2: Study area 
Table 1: Demographic properties and forest resources in the study area (GDFVR, 2010; MEFT, 2006)

\begin{tabular}{lcccccccc}
\hline Provinces & $\begin{array}{c}\text { Total area } \\
\text { (Ha) }\end{array}$ & $\begin{array}{c}\text { Total } \\
\text { population }\end{array}$ & $\begin{array}{c}\text { Forest villages } \\
\text { (units) }\end{array}$ & $\begin{array}{c}\text { Forest village } \\
\text { population }\end{array}$ & $\begin{array}{c}\text { High forests } \\
\text { (ha) }\end{array}$ & $\begin{array}{c}\text { Coppice forests } \\
\text { (ha) }\end{array}$ & $\begin{array}{c}\text { Productive forests } \\
\text { (ha) }\end{array}$ & $\begin{array}{c}\text { Unproductive forests } \\
\text { (ha) }\end{array}$ \\
\hline Afyon & 1741800 & 738979 & 156 & 59469 & 172133.0 & 52417.0 & 79713.5 & 218579.5 \\
Burdur & 713400 & 254899 & 170 & 72954 & 247867.0 & 70188.5 & 151717.0 & 166338.5 \\
Isparta & 887100 & 514379 & 160 & 86630 & 310530.5 & 53700.5 & 145651.5 & 364231.0 \\
\hline
\end{tabular}

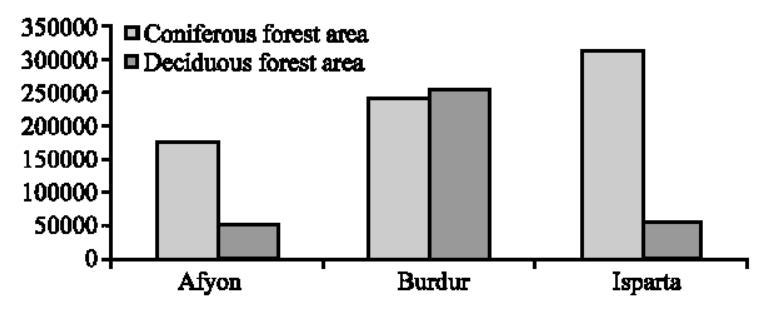

Fig. 3: Distribution of coniferous and broad-leaved forests in the forest area

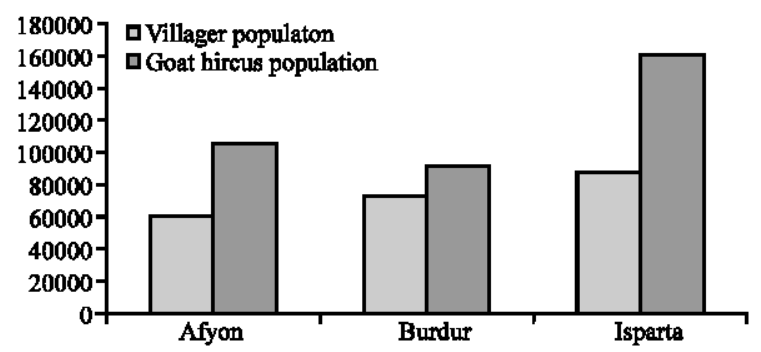

Fig. 4: Forest villager population and pure hair goat population in the study Provinces

- $\mathrm{H}_{0}$ : Variable data distributions conform with the normal distribution

- $\mathrm{H}_{1}$ : Variable data distributions do not conform with the normal distribution

- $\mathrm{H}_{0}$ : There is no statistically significant meaningful relation between the variables

- $\mathrm{H}_{1}$ : There is a statistically significant relation between the variables

- $\mathrm{H}_{0}$ : The difference between two independent Provinces is not statistically significant (the Provinces belong to the same main society)

- $\mathrm{H}_{1}$ : The difference between two independent Provinces is statistically significant (the Provinces do not belong to the same main society)

- $\mathrm{H}_{0}$ : The difference between more than two independent Provinces is not statistically significant (the provinces belong to the same main society)

- $\mathrm{H}_{1}$ : The difference between more than two independent provinces is statistically significant (the provinces do not belong to the same main society)
Table 2: Varibles used in the research

\begin{tabular}{ll}
\hline Groups & Variables \\
\hline Group 1: Pure hair goats & Raised pure hair goat population (X1) \\
Group 2:Forests & Coniferous forests (X2) \\
& Broad-leaved forests (X3) \\
& Coppice forests (X4) \\
& Total forests (X5) \\
Group 3: Population & Settlement population (X6) \\
Group 4: Ranges & X7: Range inside forests (X7) \\
& X8: Range outside forests (X8) \\
& X9: Total ranges (X9) \\
Group 5: Income & X10: Income gained from pure hair goat (X10) \\
& X11: Income gained from other activities \\
& $(\mathrm{X} 11)$ \\
& $\mathrm{X} 12:$ Total income (X12) \\
\hline
\end{tabular}

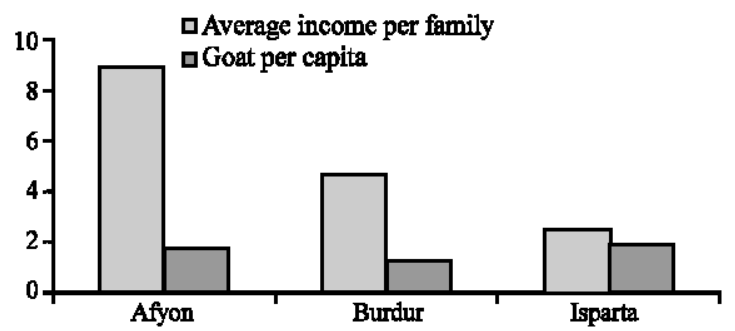

Fig. 5: Per family and per capita income in the Provinces in the study area

Statistical analyses: The first hypothesis has been tested with the One Sample Kolmogorov-Smirnov $Z$ test, the second has been tested with the Kendall tau_b and Spearman's tests, the third has been tested with the Mann-Whitney U and Two-Sample Kolmogorov-Simirnov tests and the fourth has been tested with the KruskalWallis test (Altunisik et al., 2005; Orhunbilge, 2002; Newbold, 2000). In the statistical analyses, the SPSS 11.0 (Statistical Package for Social Sciences for Windows 11.0) program has been used and the test results have been tested at a significance level of 5\% (p).

\section{RESULTS AND DISCUSSION}

Normality tests of the variable data distributions: Only the distributions of the variables X1, X2, X4, X10, X11 and $\mathrm{X} 12$ of the Province of Afyon and of the variables of X1 and X5 of the Province of Burdur are normal ( $\mathrm{p}>0.05)$ (Table 3). As a result of the normality test, it has become obligatory to utilize nonparametric methods in this research. 
Table 3: Normality (One-Sample Kolmogorov-Smimov Z test) test results

\begin{tabular}{llccccccccccc}
\hline Province & $\mathrm{X} 1$ & $\mathrm{X} 2$ & $\mathrm{X} 3$ & $\mathrm{X} 4$ & $\mathrm{X} 5$ & $\mathrm{X} 6$ & $\mathrm{X} 7$ & $\mathrm{X} 8$ & $\mathrm{X} 9$ & $\mathrm{X} 10$ & $\mathrm{X} 11$ & $\mathrm{X} 12$ \\
\hline Afyon & $0.598^{*}$ & $0.206^{*}$ & 0.000 & $0.193^{*}$ & 0.042 & 0.004 & - & - & - & $0.337^{*}$ & $0.110^{*}$ & $0.471^{*}$ \\
Burdur & $0.50^{*}$ & 0.027 & 0.000 & 0.003 & $0.053^{*}$ & 0.000 & 0.000 & 0.000 & 0.000 & 0.015 & 0.000 & 0.015 \\
Isparta & 0.000 & 0.000 & 0.000 & 0.000 & 0.025 & 0.000 & 0.000 & 0.000 & 0.000 & 0.000 & 0.000 & 0.000 \\
\hline
\end{tabular}

*Significant at the 0.05 level $(\mathrm{p}>0.05)$

Table 4: Results of the correlation test between the pure hair goat population and the other variables

\begin{tabular}{|c|c|c|c|c|c|c|c|c|c|c|c|c|c|}
\hline Province & $\mathrm{X} 1$ & Statistical result & $\mathrm{X} 2$ & $\mathrm{X} 3$ & $\mathrm{X} 4$ & $\mathrm{X} 5$ & $\mathrm{X} 6$ & $\mathrm{X} 7$ & $\mathrm{X} 8$ & $\mathrm{X9}$ & $\mathrm{X} 10$ & $\mathrm{X} 11$ & $\mathrm{X} 12$ \\
\hline \multirow[t]{4}{*}{ Afyon } & Kendall & coefficient & $-0.266^{*}$ & -0.009 & 0.245 & -0.169 & 0.023 & - & - & - & $0.798^{* * *}$ & $0.295^{*}$ & $0.796^{* *}$ \\
\hline & Tau_b & $\operatorname{Sig}(p)$ & 0.045 & 0.954 & 0.060 & 0.192 & 0.858 & - & - & - & 0.000 & 0.028 & 0.000 \\
\hline & Spearr. & coefficient & $-0.378^{*}$ & -0.011 & $0.394^{*}$ & -0.234 & 0.050 & - & - & - & $0.933^{* *}$ & $0.375^{*}$ & $0.938^{* *}$ \\
\hline & rho & $\operatorname{Sig}(p)$ & 0.039 & 0.955 & 0.031 & 0.214 & 0.794 & - & - & - & 0.000 & 0.041 & 0.000 \\
\hline \multirow[t]{4}{*}{ Burdur } & Kendall & coefficient & 0.063 & -0.003 & $0.156^{*}$ & 0.128 & $0.241^{*}$ & -0.084 & 0.022 & -0.052 & $0.631^{* *}$ & $0.225^{* *}$ & $0.623^{* *}$ \\
\hline & Tau_b & $\operatorname{Sig}(p)$ & 0.417 & 0.977 & 0.049 & 0.097 & 0.002 & 0.356 & 0.809 & 0.558 & 0.000 & 0.007 & 0.000 \\
\hline & Spear. & coefficient & 0.080 & -0.006 & 0.220 & 0.192 & $0.361^{* *}$ & -0.105 & 0.028 & -0.066 & $0.770^{* *}$ & $0.294^{* *}$ & $0.781^{* *}$ \\
\hline & rho & $\operatorname{Sig}(p)$ & 0.486 & 0.959 & 0.053 & 0.093 & 0.001 & 0.360 & 0.806 & 0.564 & 0.000 & 0.009 & 0.000 \\
\hline \multirow[t]{4}{*}{ Isparta } & Kendall & coefficient & -0.085 & -0.041 & $0.284^{* *}$ & $0.212^{* *}$ & 0.066 & -0.115 & $-0.157^{*}$ & -0.035 & $0.372^{* *}$ & $0.191^{* *}$ & $0.400^{* *}$ \\
\hline & Tau_b & Sig (p) & 0.212 & 0.580 & 0.000 & 0.000 & 0.319 & 0.139 & 0.041 & 0.630 & 0.000 & 0.009 & 0.000 \\
\hline & Spear. & coefficient & -0.118 & -0.057 & $0.388^{* *}$ & $0.326^{* *}$ & 0.084 & -0.147 & $-0.199^{*}$ & -0.056 & $0.487^{* *}$ & $0.244^{*}$ & $0.518^{* *}$ \\
\hline & rho & $\operatorname{Sig}(p)$ & 0.233 & 0.560 & 0.000 & 0.000 & 0.395 & 0.135 & 0.042 & 0.571 & 0.000 & 0.013 & 0.000 \\
\hline
\end{tabular}

*Correlation is significant at the 0.05 level (2-tailed), ${ }^{*}$ Correlation is significant at the 0.01 level (2-tailed)

Correlation between the pure hair goat population and the other variables: The correlation analysis outputs have been shown in Table 4. According to the Kendall tau b test of the Province of Afyon, the correlation between the pure hair goat population (X1) and broad-leaved forests (X2), the income gained from goats (X10), income gained from other resources (X11) and the total income (X12) is statistically significant $(\mathrm{p}<0.05)$. However, Spearman's rho test demonstrates that in addition to the other variables, there is a relation also between the variable X1 and the variable $\mathrm{X} 4(\mathrm{p}<0.05)$.

According to the Kendall tau_b test results of the Province of Burdur, the relations between the pure hair goat population (X1), coppice forests (X4), population level (X6), income gained from goats (X10), income gained from other resources (X11) and total income (X12) is statistical singificant $(\mathrm{p}<0,05)$. However, according to Spearman's rho test, there is no relation between the $\mathrm{X} 1$ variable of the Province of Burdur and the variable X4 ( $p>0.05$ ). Both tests conducted for the province of Isparta demonstrated that there is a significant relation between pure hair goat population (X1) coppice forests (X4), total forests (X5), range outside forests (X8), income gained from goats $(\mathrm{X} 10)$, income gained from other resources $(\mathrm{X} 11)$ and total income $(\mathrm{X} 12)(\mathrm{p}<0.05)$.

Testing the differences between two independent groups: The results of the Mann-Whitney $U$ and Two-Sample Kolmogorov-Simirnov $Z$ tests conducted for the purpose of designating the differences between the Provinces of Afyon-Burdur, Afyon-Isparta and Budur-Isparta (to see whether they belong to the same main society) have been shown in Table 5. The following results have been obtained from these tests: The Provinces of AfyonBurdur have been tested according to the Mann-Whitney
$\mathrm{U}$ test in terms of coniferous forests (X2), total forests (X5) and population (X6); According to the Two-Sample Kolmogorov-Simirnov $Z$ test, they do not belong to the same main society in terms of coppice forests (X4), total forests (X5), population (X6), income gained from goats $(\mathrm{X} 10)$ and total income $(\mathrm{X} 12)(\mathrm{p}<0.05)$. In other words, Afyon and Burdur are different in terms of the variables.

The Provinces of Afyon-Isparta are different in terms of broad-leaved forests (X3), coppice forests (X4), total forests (X5), population (X6) and income gained from other resources (X11) according to the Mann-Whitney $U$ test in terms of broad-leaved forests (X3), coppice forests (X4), total forests (X5), population (X6), income gained from goats $(\mathrm{X} 10)$, income gained from other resources (X11) and total income (X12) according to the TwoSample Kolmogorov-Simirnov Z test $(\mathrm{p}<0.05)$.

The Provinces of Burdur-Isparta are different from each other in terms of variables such as pure hair goat population (X1), coniferous forests (X2), broad-leaved forests (X3), coppice forests (X4) and total ranges (X9) according to the Mann-Whitney $U$ test in terms of variables such as coniferous forests (X2), broad-leaved forests (X3), coppice forests (X4) and total ranges (X11) according to the Two-Sample Kolmogorov-Simirnov $Z$ test $(\mathrm{p}<0.05)$.

Testing the differences between more than two independent groups: The outputs of the Kruskall-Wallis demonstrating whether the Provinces of Afyon, Burdur, Isparta are different have been shown in Table 6 .

As it may be shown in Table 6, Afyon, Burdur and Isparta are different from each other in terms of variables such as pure hair goat population (X1), coniferous forests (X2), broad-leaved forests (X3), coppice forests (X4), total 
Table 5: Analysis outputs relating to the comparison of two independent groups (provinces)

\begin{tabular}{|c|c|c|c|c|c|c|c|c|c|c|c|c|c|}
\hline Groups & Test cofficient & $\mathrm{X} 1$ & $\mathrm{X} 2$ & $\mathrm{X} 3$ & $\mathrm{X} 4$ & $\mathrm{X} 5$ & $\mathrm{X} 6$ & $\mathrm{X} 7$ & $\mathrm{X} 8$ & $\mathrm{X} 9$ & $\mathrm{X} 10$ & $\mathrm{X} 11$ & $\mathrm{X} 12$ \\
\hline \multicolumn{14}{|l|}{ Afyon-burdur } \\
\hline Mann-Whitney U & $\mathrm{U}$ & 1074.5 & 778 & 1041.5 & 1088.5 & 636 & 664.5 & - & - & - & 905.5 & 949.5 & 923.5 \\
\hline \multirow[t]{2}{*}{ Wilcoxon W } & W & 4155.5 & 1243 & 1506.5 & 1553.5 & 1101 & 1129.5 & - & - & - & 3986.5 & 3952.5 & 004.5 \\
\hline & $\mathrm{p}$ & 0.512 & $0.007^{*}$ & 0.106 & 0.575 & $0.000^{*}$ & $0.001^{*}$ & - & - & - & 0.070 & 0.138 & 0.091 \\
\hline Two samp. & Z & 0.776 & 1.325 & 0.501 & 1.420 & 1.993 & 1.790 & - & - & - & 1.707 & 1.080 & 1.468 \\
\hline Kolmo-Simimov & $\mathrm{p}$ & 0.584 & 0.060 & 0.963 & $0.035^{*}$ & $0.001^{*}$ & $0.000^{*}$ & - & - & - & $0.006^{*}$ & 0.194 & $0.027^{+}$ \\
\hline \multicolumn{14}{|l|}{ Afyon-isparta } \\
\hline Mann-Whitney & $\mathrm{U}$ & 1354 & 1520 & 1040 & 1195 & 1121.5 & 711 & - & - & - & 1327 & 1150 & 1272 \\
\hline \multirow[t]{2}{*}{ Wilcoxon tests } & W & 1819 & 7085 & 1505 & 6760 & 1586.5 & 1176 & - & - & - & 6892 & 6610 & 6837 \\
\hline & $\mathrm{p}$ & 0.242 & 0.768 & $0.000^{*}$ & $0.039^{*}$ & $0.016^{*}$ & $0.000^{*}$ & - & - & - & 0.189 & $0.019^{*}$ & 0.109 \\
\hline Two samp. & $\mathrm{Z}$ & 0.920 & 0.759 & 1.633 & 2.346 & 1.863 & 2.530 & - & - & - & 1.380 & 1.429 & 1.380 \\
\hline Kolmo-Simimov & $\mathrm{p}$ & 0.366 & 0.612 & $0.010^{*}$ & $0.000^{*}$ & $0.002^{*}$ & $0.000^{*}$ & - & - & - & $0.044^{*}$ & $0.034^{*}$ & $0.044^{*}$ \\
\hline \multicolumn{14}{|l|}{ Burdur-isparta } \\
\hline Mann-Whitney & $\mathrm{U}$ & 3202 & 2723 & 3175 & 3344 & 3490.5 & 3524.5 & 3969 & 3772.5 & 3374 & 4088 & 3647.5 & 4000.5 \\
\hline \multirow[t]{2}{*}{ Wilcoxon tests } & W & 6283 & 8288 & 6256 & 8909 & 9055.5 & 6605.5 & 7050 & 6853.5 & 6455 & 7169 & 9107.5 & 9565.5 \\
\hline & $\mathrm{p}$ & $0.012^{*}$ & $0.000^{*}$ & $0.001^{*}$ & $0.029^{*}$ & 0.088 & 0.107 & 0.576 & 0.164 & $0.015^{*}$ & * 0.984 & 0.270 & 0.790 \\
\hline Two samp. & $\mathrm{Z}$ & 1.277 & 2.031 & 1.541 & 1.534 & 1.098 & 1.098 & 0.250 & 0.630 & 1.497 & 0.772 & 0.728 & 1.015 \\
\hline Kolmo-Simimov & $\mathrm{p}$ & 0.077 & $0.001^{*}$ & $0.017^{*}$ & $0.018^{*}$ & 0.179 & 0.179 & 1.000 & 0.823 & $0.023^{*}$ & * 0.590 & 0.665 & 0.255 \\
\hline
\end{tabular}

${ }^{*}$ When $\mathrm{p}<0.05$, The hypothesis claiming that $\mathrm{H}_{0}$; Provinces belong to the same main society is being rejected; U: Mann-Whitney U test coefficient, $\mathrm{W}$ : Wilcoxon $\mathrm{W}$ test coefficient

Table 6: Analysis outputs relating to the comparison of 3 independent groups

\begin{tabular}{llllllllll}
\hline Kruskall-Wallis & $X 1$ & $X 2$ & $X 3$ & $X 4$ & $X 5$ & $X 6$ & $X 10$ & $X 11$ & \\
\hline Afyon-burdur-isparta & & & & & & & & \\
$\chi^{2}$ & 6.548 & 16.774 & 20.151 & 6.572 & 12.990 & 21.633 & 2.700 & 5.639 & 3.124 \\
Sig. (p) & 0.038 & 0.000 & 0.000 & 0.037 & 0.002 & 0.000 & 0.259 & 0.060 & 0.210 \\
\hline
\end{tabular}

forests (X5) and population $(\mathrm{X} 6)(\mathrm{p}<0.05)$. A relation between pure hair goat population and coniferous forests is observed only in the province of Afyon. However, the weakness of this relation demonstrates that only coniferous forests should not be taken into account in the decisions regarding pure hair goats. The most conspicuous aspect is that the correlation is marked negative. The increase of pure hair goat population in this province means that coniferous forests are decreasing. This result complies with literature (MEFT, 2008; Gulen, 1978; Pariset et al., 2009; Tolunay et al., 2009).

No statistically significant relation has been determined between pure hair goat population and broad leaved forests in any of the provinces. In accordance with this result which complies with literature, broadleaved forests is negligible while designating policies on pure hair goat populations (Gulen, 1978; MEFT, 2008).

The correlation between pure hair goat populations and coppice forests is positive and weak in all of the Provinces of Afyon, Burdur and Isparta. This result complies with literature (MEFT, 2008). In addition to other variables also coppice forests should be taken into account when designating policies. The fact that the calculated correlation coefficient bears a positive sign demonstrates that the increase in coppice forests has an also an increasing impact on pure hair goat population (MEFT, 2008). There is a statistically significant and positive relation between pure hair goat population and the total forests only in the Province of Isparta. Thus, this variable should be taken into account when designating the policy relating to pure hair goats in the Province of Isparta. The attitude applies for the pure hair goat policy implemented in the Province of Isparta.

The significant and positive relation between the pure hair goat population and the population applies only for the Province of Burdur. Thus, also the population variable should be taken into account when designating the policy regarding pure hair goats in the Province of Burdur. No statistically significant relation has been designated between the pure hair goat population and ranges outside forests in the Provinces of Burdur and Isparta. This demonstrates that ranges outside forests in these provinces are negligible when designating the policy on pure hair goat population.

A statistically significant and negative relation has been determined only in the Province of Isparta among the pure hair goat population and ranges outside forests. However, the fact that the significance values (p) of decision tests are very close $(5 \%)$ demonstrates that also this variable is negligible.

No statistically significant relation has been designated between the pure hair goat population and the total ranges in the Provinces of Burdur and Isparta. This result demonstrates that the ranges in these provinces are negligible when designating the policies regarding the pure hair goat population. The relation between the pure hair goat population and the income gained from goats is strong in all Provinces of Afyon, Burdur and Isparta; it is 
very strong in the Province of Afyon and strong in the provinces of Burdur and Isparta. This result demonstrates that it is absolutely necessary to take into account the income gained from goats and the total income variables when designating the policies regarding pure hair goats in these three provinces. In (MEFT, 2008) the principle for providing an alternative source of living to the villagers whose number of pure hair goats is reduced has been adopted.

The relation between pure hair goat raising, income gained from goats and the total income designated in the study complies with literature (Babalik and Fakir, 2007; Yilmaz et al., 2006). In the provinces located in the study area, pure hair goats per villager in Isparta, Afyon and Burdur is $1.88,1.74$ and 1.23 , respectively. The annual per family average income of the villagers that borrowed a loan from the General Directorate of Forest Village Relations as of 2006 is US\$ 6,669, US\$3,464 and US\$1,866, in Afyon, Burdur and Isparta, respectively'dir (GDFVR, 2010). According to MEFT 2008 data, the pure hair goat population raised in the three provinces constitutes $14 \%$ of the total of the Mediterranean and Aegean Regions and $5.63 \%$ of Turkey as a whole. The market value of goat milk was US\$ 49,415 751 in 2006 (TSI, 2010). As it may be observed, pure hair goats stand as a major source of living in the study area and especially in the province of Isparta.

A positive and weak relation is observed between pure hair goat population and the income gained from other resources in all three provinces. In terms of the variables analyzed in the Provinces of Afyon, Burdur and Isparta, accepted to have similar geographic conditions, their differences according to double and triple comparison results have been provided below:

The Provinces of Afyon-Burdur are different in terms of characteristics such as coniferous forests, coppice forests, total forests, population, income gained from goats and total income. The Provinces of Afyon-Isparta are different from each other in terms of broad-leaved forests, coppice forests, total forests, population, income gained from goats, income gained from other resources and total income.

The Provinces of Burdur and Isparta are different in terms of characteristics relating to pure hair goat population, coniferous forests, broad-leaved forests, coppice forests and total ranges.

The Provinces of Afyon, Burdur and Isparta are different from each other in terms of pure hair goat population, coniferous forests, broad-leaved forests, total forests and population.

\section{CONCLUSION}

In conclusion, double and triple independent group difference tests have proven that the a priori assumption that there is strong relation between pure hair goats, forests, pastures and population and that the settlements within the borders of the same region are similar in terms of pure hair goats, forests, ranges, population and income levels do not apply for the Provinces of Afyon, Burdur and Isparta and that relation analyses have proven that the correlation between factors change on a province basis. These findings demonstrate that when effective and optimum solutions are targeted for the problems, local differences should certainly be taken into account.

\section{ACKNOWLEDGEMENTS}

The data relating to the Provinces of Afyon, Burdur and Isparta which were used in the statistical assessments by the researchers of this study have been procured from the Isparta Regional Directorate of Forestry. The researchers would like to extend their acknowledgment to the Deputy Regional Director of Forestry, Adnan Yilmazturk for his contribution and assistance.

\section{REFRENCES}

Altunisik, R., R. Coskun, S. Bayraktaroglu and E. Yildirim, 2005. Research Methods in Social Sciences-Applied SPSS. Sakarya Bookstore Publishing, Sakarya, pp: 359.

Babalik, A.A. and H. Fakir, 2007. The Effects of Goat Grazing on Leaf Morphology of Some Shrub Species in Kozagaci Highland of Davraz Mountain (Isparta). Suleyman Demirel University, Isparta, pp: 1-8.

Bassullu, C. and A. Tolunay, 2010a. Analysis on traditional homegarden involving animals practices and its importance classification of usage purposes in rural areas of isparta region of Turkey. Asian J. Anim. Vet. Adv., 5: 450-464.

Bassullu, C. and A. Tolunay, 2010b. General characteristics of traditional homegarden involving animal practices in rural areas of isparta region of Turkey. J. Anim. Vet. Adv., 9: 455-465.

GDFVR, 2010. Provincial action plan (2008-2012). General Directorate of Forest and Village Relations. http://www.orkoy.gov.tr.

Gulen, I., 1978. Problem of Goat Grazing. Istanbul Univiersity, Istanbul, pp: 65-73.

MEFT, 2008. Action Plan for Reducing the Harms of Goats. Ministry Environment and Forestry of Turkey, Ankara, pp: 40. 
MEFT., 2006. Our forests. Ministry Environment and Forestry of Turkey, Ankara, pp: 160.

Newbold, P., 2000. Statistics for Business Economics. 4th Edn., Translated Umit Senesen, Istanbul Tech. University, Istanbul, ISBN: 975-843120-X, pp: 983

Orhunbilge, N., 2002. Applied Regression and Correlation Analysis. Istanbul Uni. Publication, Istanbul, ISBN: 975-404-649-X, pp: 340.

Pariset, L., A. Cuteri, C. Ligda, P. Ajmone-Marsan, A. Valentini and E. Consortium, 2009. Geographical patterning of sixteen goat breeds from Italy, Albania and Greece assessed by single nucleotide polymorphisms. BMC. Ecol., 9: 20-20.

SPO, 1996a. Afyon Province Report. State Planning Organization, Ankara, pp: 91.
SPO, 1996b. Burdur Province Report. State Planning Organization, Ankara, pp: 104.

TSI, 2010. Statistical Indicators 1923-2008. 1st. Edn., Turkish Statistical Institute, Ankara.

Temurcin, K., 2004. The economic geography of the province Isparta. Ph.D. Thesis, Ankara Univ., Social Sciences Ins., Ankara, pp:397.

Tolunay, A., A. Akyol, U. Ince and V. Ayhan, 2009. Traditional usage of kermes oak (Quercus coccifera L.) and pure hair goat (Capra hircus L.) in a silvopastoral system on davras mountain in anatolia: Constraints, problems and possibilities. J. Anim. Vet. Adv., 8: 1520-1526.

Yilmaz, H., V. Demircan and Z. Dernek, 2006. Agricultural structure of Isparta province, production and development potential. Suleyman Demirel Univ. J. Agric. Fac. 1: 1-6. 